\title{
Lyotropic Liquid-Crystalline Phase of Oligo(ethylene oxide) Surfactant/Transition Metal Salt and the Synthesis of Mesostructured Cadmium Sulfide
}

\author{
Ömer Dag,* Selim Alayoǧlu, Cenk Tura, and Özgür Çelik \\ Department of Chemistry, Bilkent University, 06800, Ankara, Turkey
}

Received March 13, 2003. Revised Manuscript Received May 6, 2003

\begin{abstract}
Lyotropic liquid-crystalline ( $L L C$ ), transition metal salt:oligo(ethylene oxide) nonionic surfactant $\left(\mathrm{C}_{n} \mathrm{H}_{2 n+1}\left(\mathrm{CH}_{2} \mathrm{CH}_{2} \mathrm{O}\right)_{m} \mathrm{OH}\right.$, denoted as $\left.\mathrm{C}_{n} \mathrm{EO} \mathrm{O}_{m}\right)$, systems have been studied by means of diffraction, microscopy, and spectroscopy to elucidate the structural, thermal, and templating properties. In the system, the lyotropic salts of transition metal aqua complexes, such as chlorides and sulfates, are insoluble and do not form a LC phase in $\mathrm{C}_{n} E \mathrm{O}_{\mathrm{m}}$-type nonionic surfactants. However, the transition metal aqua complexes of nitrates and perchlorates are soluble and form 2D and 3D hexagonal and cubic mesophases. These phases are stable in a very broad range of salt:surfactant mole ratios (1.0 and 3.6). The nitrate salts form a hexagonal mesophase. However, in high nitrate salt concentrations (above 3.2 salt:surfactant mole ratio), the salt crystals are either insoluble or the salt:surfactant mixtures are in a cubic mesophase. The structure and thermal properties of the new system are determined by the solubility of the transition metal salts, the concentration of the salt, and the surfactant type. The $\mathrm{LC}\left[\mathrm{Cd}\left(\mathrm{H}_{2} \mathrm{O}\right)_{4}\right]\left(\mathrm{NO}_{3}\right)_{2}: \mathrm{C}_{12} \mathrm{EO}_{10}$ mesophase has been reacted with $\mathrm{H}_{2} \mathrm{~S}$ gas to produce solid mesostructured CdS (meso- $\mathrm{CdS}$ ). The meso-CdS particles are spherical in morphology and are made up of hierarchical organization of 2-4-nm CdS particles. The salt:surfactant LLC systems and the solid meso-CdS have been investigated using polarized optical microscopy, X-ray diffraction, Fourier transform infrared, Fourier transform Raman, and UV-vis absorption spectroscopy, scanning el ectron mi croscopy, and transmission electron microscopy.
\end{abstract}

\section{Introduction}

Since the discovery of surfactants as templates for the synthesis of mesoporous materials, ${ }^{1}$ there is a fast growing interest in many fields of surfactant and materials chemistry. The oligo(ethylene oxide) nonionic surfactants $\left(\mathrm{C}_{n} \mathrm{H}_{2 n+1}\left(\mathrm{CH}_{2} \mathrm{CH}_{2} \mathrm{O}\right)_{m} \mathrm{OH}\right.$, denoted as $\mathrm{C}_{n}$ $\mathrm{EO}_{\mathrm{m}}$ ) were also used in many of these studies as a template to produce mesoporous and/or mesostructured material s. ${ }^{2-13}$ These surfactants have a lyotropic liquidcrystalline (LLC) mesophase in water. ${ }^{14-16}$ The LLC

* To whom correspondence should be addressed. Phone: 90312290 3918. Fax: 90312266 4579. E-mail: dag@fen.bilkent.edu.tr.

(1) Kresge, C. T.; Leonowicz, M. E.; Roth, W. J .; Vartuli, J . C.; Beck, J. S. Nature 1992, 359, 710

(2) Attard, G. S.; Glyde, J . C.; Göltner, C. G. Nature 1995, 378, 366.

(3) Attard, G. S.; Göltner, C. G.; Corker, J . M.; Henke, S.; Templer

R. H. Angew. Chem., Int. Ed. Engl. 1997, 36, 1315.

(4) Attard, G. S.; Bartlett, P. N.; Coleman, N. R. B.; Elliott, J . M.; Owen, J . R.; Wang, J. H. Science 1997, 278, 838.

(5) Braun, P. V.; Osenar, P.; Stupp, S. I. Nature 1996, 380, 325

(6) Osenar, P.; Braun, P. V.; Stupp, S. I. Adv. Mater. 1996, 8, 1022.

(7) Tanev, P. T.; Pinnavaia, T. J. Chem. Mater. 1996, 8, 2068.

(8) Zhao, D.; Huo, Q.; Feng, J.; Chmelka, B. F.; Stucky, G. D. J . Am. Chem. Soc. 1998, 120, 6024

(9) Dag, Ö.;Y oshina-Ishii, C.; Asefa, T.; MacLachlan, M.J .; Grondey, H.; Coombs, N.; Ozin, G. A. Adv. Funct. Mater. 2001, 11, 213. 203.

(11) Dag, Ö.; Soten, I.; Çelik, Ö.; Polarz, S.; Coombs, N.; Ozin, G. A. Adv. Funct. Mater. 2003, 13, 30 .

(12) Dag, Ö.; Samarskaya, O.; Coombs, N.; Ozin, G. A. J . Mater. Chem. 2003, 13, 328.

(13) J iang, X.; Xie, Y.; Lu, J .; Zhu, L.; He, W.; Qian, Y. Chem. Mater. 2001, 13, 1213 . phase of a nonionic surfactant occurs because the oillike tail group (alkyl group, $\mathrm{C}_{n} \mathrm{H}_{2 n+1}-$ ) of the $\mathrm{C}_{n} \mathrm{EO}_{m}$ molecule tends to minimize the interaction with the water molecules; however, the polar EO headgroup $\left(-\left(\mathrm{CH}_{2} \mathrm{CH}_{2} \mathrm{O}\right)_{\mathrm{m}} \mathrm{OH}\right)$ tends to stay outside, to form micelle in dilute water solutions. The surfactant-rich end of a mixture of nonionic surfactant and water usually has a liquid-crystalline (LC) mesophase with a welldefined structure, such as bicontinuous cubic and hexagonal mesophases. ${ }^{15}$ Usually the metal or complex salts are added to the LC media as a third or fourth component. ${ }^{3-7,10-12}$ The LC mesophase is formed by the water molecules through polar-apolar interactions and the salts are dissolved in the water region (hydrophilic) of the LC mesophase. ${ }^{3-7,10-12}$ The hydrogen-bonding interactions between the inorganic ingredients and the nonionic surfactant molecules organize the inorganic precursors into a mesoporous and/or mesostructured framework. ${ }^{2-13}$

Recently, Gin and co-workers ${ }^{17-19}$ have developed a novel approach to producing nanocomposites using a

(14) Mitchell, D. J .; Tiddy, G. J. T.; Waring, L.; Bostock, T.; McDonald, M. P. J. Chem. Soc., Faraday Trans. 1983, 79, 975.

(15) Sakya, P.; Seddon, J . M.; Templer, R. H.; Mirkin, R. J .; Tiddy, G. J. T. Langmuir 1997, 13, 3706.

(16) Nishizawa, M.; Saito, K.; Sorai, M.J . Phys. Chem. B 2001, 105, 2987.

(17) Gray, D. H.; Gin, D. L. Chem. Mater. 1998, 10, 1827.

(18) Deng, H.; Gin, D. L.; Smith, R. C. J . Am. Chem. Soc. 1998 120, 3522. 
similar idea by a cross-linkable LLC mesophase. The LLC mesogen retains its microstructure, which consists of a polymerizable ionic mesogen and reactive hydrophilic precursors (such as transition metals and lanthanides). For example, a reaction of $\mathrm{H}_{2} \mathrm{~S}$ gas with a $\mathrm{Cd}(\mathrm{II})$-containing mesophase has produced $40-\AA \AA \mathrm{CdS}$ nanoparticles within the hydrophilic channels. ${ }^{17}$

In all these salt-involved LLC systems, the counteranions, which can be classified into two groups, either lyotropic or hydrotropic anions, ${ }^{20-24}$ play important roles in the stability of the LC mesophase in water/surfactant systems. The lyotropic anions, such as $\mathrm{Cl}^{-}$and $\mathrm{SO}_{4}{ }^{2-}$ ions, reduce the solubility between the surfactant and water molecules (salting out effect); however, the hydrotropic anions such as $\mathrm{NO}_{3}{ }^{-}$and $\mathrm{ClO}_{4}{ }^{-}$ions ${ }^{20,21}$ increase the mutual solubility between the surfactant and water molecules (salting in effect).

Recently, we introduced a new salt:nonionic surfactant LLC system that was obtained by dissolving the nitrate salts of some first and second row transition metal aqua complexes in $\mathrm{C}_{12} \mathrm{EO}_{10}$ at high salt concentrations. ${ }^{25,26}$ In the new system, the coordinated water molecules mediate the formation of a hexagonal and/or cubic LC mesophase. In this article, the new salt: surfactant binary systems of two different nonionic surfactants, such as $\mathrm{C}_{12} \mathrm{EO}_{10}$ and $\mathrm{C}_{16} \mathrm{EO}_{10}$ with some of the first and second row transition metal aqua complexes of chloride, nitrate, and perchlorate salts, have been investigated. The reaction of $\mathrm{H}_{2} \mathrm{~S}$ gas with the cadmium nitrate: $\mathrm{C}_{12} \mathrm{EO}_{10}$ LLC systems produced mesostructured CdS (meso-CdS) materials. The structural properties of the salt:surfactant LLC systems and the mesostructured cadmium sulfide have been studied by various techniques, such as polarized optical microscopy (POM), scanning electron microscopy (SEM), transmission electron microscopy (TEM), powder X-ray diffraction (PXRD), and Fourier transform infrared (FT-IR), Fourier transform Raman (FTR), and UV-vis absorption spectroscopies.

\section{Experimental Section}

Materials. All chemicals and solvents were reagent grade and used as received without any further treatment. The surfactants used throughout this work, homogeneous polyoxyethylene 10 lauryl ether $\left(\mathrm{C}_{12} \mathrm{E}_{10}\right)$ and polyoxyethylene 10 cetyl ether $\left(\mathrm{C}_{16} \mathrm{EO}_{10}\right)$, are commercially available from Sigma. Cobalt(II) nitrate hexahydrate $\left(\left[\mathrm{Co}\left(\mathrm{H}_{2} \mathrm{O}\right)_{6}\right]\left(\mathrm{NO}_{3}\right)_{2}, 99 \%\right)$, cobalt(II) chloride hexahydrate $\left(\left[\mathrm{Co}\left(\mathrm{H}_{2} \mathrm{O}\right)_{6}\right] \mathrm{Cl}_{2}, 98 \%\right)$, cobalt(II) perchlorate hexahydrate $\left(\left[\mathrm{Co}\left(\mathrm{H}_{2} \mathrm{O}\right)_{6}\left(\mathrm{ClO}_{4}\right)_{2}\right)\right.$, zinc(II) perchlorate hexahydrate $\left(\left[\mathrm{Zn}\left(\mathrm{H}_{2} \mathrm{O}\right)_{6}\left(\mathrm{ClO}_{4}\right)_{2}\right)\right.$, cadmium(II) perchlorate hexahydrate $\left(\left[\mathrm{Cd}\left(\mathrm{H}_{2} \mathrm{O}\right)_{4}\right]\left(\mathrm{ClO}_{4}\right)_{2}\right)$, manganese(II) nitrate tetrahydrate $\left(\left[\mathrm{Mn}\left(\mathrm{H}_{2} \mathrm{O}\right)_{4}\right]\left(\mathrm{NO}_{3}\right)_{2}, 99 \%\right)$, cobalt(II) sulfate hexahydrate $\left(\left[\mathrm{Co}\left(\mathrm{H}_{2} \mathrm{O}\right)_{6}\right] \mathrm{SO}_{4}\right)$, nickel(II) sulfate hexahydrate ([Ni$\left.\left.\left(\mathrm{H}_{2} \mathrm{O}\right)_{6}\right] \mathrm{SO}_{4}, 99 \%\right)$, zinc(II) sulfate hexahydrate $\left(\left[\mathrm{Zn}\left(\mathrm{H}_{2} \mathrm{O}\right)_{6}\right] \mathrm{SO}_{4}\right.$ $98+\%)$, cadmium(II) sulfate hexahydrate $\left(\left[\mathrm{Cd}\left(\mathrm{H}_{2} \mathrm{O}\right)_{4}\right] \mathrm{SO}_{4}\right.$, $99 \%)$, and hydrogen sulfide $\left(\mathrm{H}_{2} \mathrm{~S}, 99.5 \%\right.$ pure) were obtained

(19) Gin, D. L.; Gu, W.; Pindzola, B. A.; Zhou, W.-J . Acc. Chem. Res. 2001, 34, 973 1937.

(20) Kahlweit, M.; Lessner, E.; Strey, R. J . Phys. Chem. 1984, 88, 163.

(22) Rodriguez, C.; Kunieda, H. Langmuir 2000, 16, 8263.

(23) I wanaga, T.; Suzuki, M.; Kunieda, H. Langmuir 1998, 14, 5775.

(24) Schott, H. J . Colloid Interface Sci. 1997, 189, 117.

(25) Çelik, Ö.; Dag, Ö. Angew. Chem., Int. Ed. 2001, 40, 3800.

(26) Dag, Ö.; Samarskaya, O.; Tura, C.; Günay, A.; Çelik, Ö. Langmuir 2003, 19, 3671. from Aldrich. Nickel(II) nitrate hexahydrate $\left(\left[\mathrm{Ni}\left(\mathrm{H}_{2} \mathrm{O}\right)_{6}\right]\left(\mathrm{NO}_{3}\right)_{2}\right.$, $97 \%$ pure), zinc(II ) nitrate hexahydrate $\left(\left[\mathrm{Zn}\left(\mathrm{H}_{2} \mathrm{O}\right)_{6}\right]\left(\mathrm{NO}_{3}\right)_{2}, 99 \%\right.$ pure), and cadmium(II ) nitrate tetrahydrate $\left(\left[\mathrm{Cd}\left(\mathrm{H}_{2} \mathrm{O}\right)_{4}\right]\left(\mathrm{NO}_{3}\right)_{2}\right.$, 99\% pure) were obtained from Merck and Aldrich.

Sample Preparation. All samples were prepared by direct mixing the surfactant, $\mathrm{C}_{12} \mathrm{H}_{25}\left(\mathrm{CH}_{2} \mathrm{CH}_{2} \mathrm{O}\right)_{10} \mathrm{OH}$ (represented $\mathrm{C}_{12^{-}}$ $\mathrm{EO}_{10}$ ) and/or $\mathrm{C}_{16} \mathrm{EO}_{10}$ and metal complex salts, such as [Co$\left.\left(\mathrm{H}_{2} \mathrm{O}\right)_{6}\right]\left(\mathrm{NO}_{3}\right)_{2},\left[\mathrm{Co}\left(\mathrm{H}_{2} \mathrm{O}\right)_{6}\right] \mathrm{Cl}_{2},\left[\mathrm{Ni}\left(\mathrm{H}_{2} \mathrm{O}\right)_{6}\right]\left(\mathrm{NO}_{3}\right)_{2},\left[\mathrm{Zn}\left(\mathrm{H}_{2} \mathrm{O}\right)_{6}\right]-$ $\left(\mathrm{NO}_{3}\right)_{2}$, and $\left[\mathrm{Cd}\left(\mathrm{H}_{2} \mathrm{O}\right)_{4}\right]\left(\mathrm{NO}_{3}\right)_{2},\left[\mathrm{Mn}\left(\mathrm{H}_{2} \mathrm{O}\right)_{4}\right]\left(\mathrm{NO}_{3}\right)_{2},\left[\mathrm{Co}\left(\mathrm{H}_{2} \mathrm{O}\right)_{6}\right]-$ $\left(\mathrm{ClO}_{4}\right)_{2},\left[\mathrm{Zn}\left(\mathrm{H}_{2} \mathrm{O}\right)_{6}\right]\left(\mathrm{ClO}_{4}\right)_{2},\left[\mathrm{Cd}\left(\mathrm{H}_{2} \mathrm{O}\right)_{4}\right]\left(\mathrm{ClO}_{4}\right)_{2}$, and $\left[\mathrm{Co}\left(\mathrm{H}_{2} \mathrm{O}\right)_{6}\right]-$ $\mathrm{SO}_{4},\left[\mathrm{Ni}\left(\mathrm{H}_{2} \mathrm{O}\right)_{6}\right] \mathrm{SO}_{4},\left[\mathrm{Zn}\left(\mathrm{H}_{2} \mathrm{O}\right)_{6}\right] \mathrm{SO}_{4}$, and $\left[\mathrm{Cd}\left(\mathrm{H}_{2} \mathrm{O}\right)_{4}\right] \mathrm{SO}_{4}$ (which are denoted as $\mathrm{MY}$ ) in the solid phase. One gram of surfactant $\left(1.595 \times 10^{-3} \mathrm{~mol}\right)$ is mixed with metal salts, in mole ratios of $\left(\mathrm{MY} / \mathrm{C}_{\mathrm{n}} \mathrm{EO}_{\mathrm{m}}\right) ; 0.0-7.0$. Then, the mixture was either heated to its melting point or dissolved in methanol or water that could be pumped out under vacuum or dried in air to obtain homogeneous mixtures. However, most of the samples used throughout this work were prepared by heating above the melting point, shaking constantly, and then cooling to room temperature (RT). The heating and cooling cycles were re peated several times to achieve homogeneity. Finally, the samples were kept bel ow their melting point for several hours. However, overheating, especially in the case of $\left[\mathrm{Cd}\left(\mathrm{H}_{2} \mathrm{O}\right)_{4}\right]-$ $\left(\mathrm{NO}_{3}\right)_{2}$ samples, may destroy the $\mathrm{LC}$ mesophase.

The samples of surfactant-water-metal salt were prepared by mixing 50:50 wt \% of water and surfactant (1g of water, $1 \mathrm{~g}$ of surfactant) and then $\left[\mathrm{Ni}\left(\mathrm{H}_{2} \mathrm{O}\right)_{6}\right]\left(\mathrm{NO}_{3}\right)_{2},\left[\mathrm{Co}\left(\mathrm{H}_{2} \mathrm{O}\right)_{6}\right]\left(\mathrm{NO}_{3}\right)_{2}$, and $\left[\mathrm{Co}\left(\mathrm{H}_{2} \mathrm{O}\right)_{6}\right] \mathrm{Cl}_{2}$ salts were added to the above mixture in a range of $\mathrm{MY} / \mathrm{C}_{12} \mathrm{EO}_{10}$ mole ratio, 0.0-1.0. The same procedure, which was applied to the water-free samples, was used to homogenize the samples.

Synthesis of meso-CdS. A liquid-crystalline $\left[\mathrm{Cd}\left(\mathrm{H}_{2} \mathrm{O}\right)_{4}\right]$ $\left(\mathrm{NO}_{3}\right)_{2}: \mathrm{C}_{12} \mathrm{EO}_{10}$ mesophase with a different mole ratio was prepared as described above. The thin films of these samples, prepared on quartz windows, were exposed to 100-200 Torr of $\mathrm{H}_{2} \mathrm{~S}$ gas in a specially designed, evacuated glass reaction cell for 30 min to 1 day (depending on the thickness of the sample). The powder samples were prepared in a Schlenk line, which was purged with $\mathrm{H}_{2} \mathrm{~S}$ gas under vacuum. Addition of $\mathrm{H}_{2} \mathrm{~S}$ gas to film and/or bulk samples immediately produces the yellow product. Then, the products were washed with ethanoldiethyl ether solution several times to remove unreacted complexes and most of the surfactant molecules. To col lect the products, the ethanol-diethyl ether solutions were centrifuged and the products were dried at RT.

Characterization. POM Images. The POM images were recorded on a Stereo Microscope Stemi 2000 with a halogen lamp, $6 \mathrm{~V} / 10 \mathrm{~W}$, equipped for bright field and phase contrast and a Meije Techno M L 9400 series polarizing microscope using convergent whitelight. The thermal properties of the mixtures were studied using a Leica microscope heating stage 350 attached to the above microscope. The hot stage, which was calibrated against the melting point of naphthalene, was operated with a $3^{\circ} \mathrm{C} / \mathrm{min}$ heating rate.

X-ray Diffraction (XRD) Patterns. The XRD patterns were recorded on a Rigaku Miniflex diffractometer using a highpower $\mathrm{Cu} \mathrm{K} \alpha$ source operating at $30 \mathrm{kV} / 15 \mathrm{~mA}$. The samples, which are in a LC phase, were prepared on 0.2- and/or 0.5$\mathrm{mm}$ glass sample holders. The XRD patterns were recorded twice for each sample. The first measurements were carried on a less ordered sample (unoriented) and the second on the oriented form, which can be obtained by heating the samples up to IT and cooling to ambient temperature. The PXRD patterns of meso-CdS powder samples were recorded in 0.5$\mathrm{mm}$ glass sample holders.

Micro-Raman Spectra. The micro-Raman spectra were obtained on a S. A. LabRam confocal Raman microscope. The signal collected was transmitted through a fiber optic cable into a single grating spectrometer equipped with a $1024 \times 256$ element CCD. The Raman spectra were collected by manually placing the probe tip near the desired point of the film and/or powder particles.

FT-IR Spectra. FT-IR spectra were recorded on a Bomem Hartman MB-102 model FT-IR spectrometer. A standard DTGS detector was used with a resolution of $4 \mathrm{~cm}^{-1}$. The 
spectra were recorded as thin films on an undopped Si(100) wafer for the binary systems ( $\left.M Y: C_{n} E O_{m}\right)$ and between two $\mathrm{Si}(100)$ wafers for the ternary systems (MY: $\mathrm{H}_{2} \mathrm{O}: \mathrm{C}_{n} E \mathrm{O}_{m}$, prepared using 50 wt \% water/surfactant).

UV-Vis Absorption Spectra. The UV-vis absorption spectra were recorded using a Varian Cary 5 double-beam spectrophotometer with $150 \mathrm{~nm} / \mathrm{min}$ speed with a resolution of $2 \mathrm{~nm}$ over a wavelength range from 1400 to $200 \mathrm{~nm}$. The UV-vis absorption spectra of the meso- $\mathrm{CdS}$ samples were recorded using $\mathrm{H}_{2} \mathrm{~S}$-treated thin films of the $\left[\mathrm{Cd}\left(\mathrm{H}_{2} \mathrm{O}\right)_{4}\right]\left(\mathrm{NO}_{3}\right)_{2}: \mathrm{C}_{12} \mathrm{EO}_{10}$ $\mathrm{LC}$ systems on quartz windows.

TEM Images. The TEM images were recorded at $300 \mathrm{kV}$ using a JEOL 3010. The TEM samples of meso-CdS were prepared under ambient conditions by depositing a droplet of ethanol-meso-CdS suspension on to a carbon film, which is supported on a copper grid.

SEM I mages. The SEM images were recorded at 16 and 25 kV using a J EOL 6400. The SEM specimen of the meso-CdS was prepared under ambient conditions by depositing a droplet of ethanol-meso-CdS suspension onto a metal SEM sample holder.

\section{Results and Discussion}

LLC Binary and Ternary Systems. Dissolving some of the first and second row transition metal aqua complex salts $\left(\left[\mathrm{M}\left(\mathrm{OH}_{2}\right)_{6}\right] \mathrm{X}_{2}\right.$ and $\left[\mathrm{M}^{\prime}\left(\mathrm{OH}_{2}\right)_{4}\right] \mathrm{X}_{2}\left(\mathrm{M}=\mathrm{Co}^{2+}\right.$, $\mathrm{Ni}^{2+}, \mathrm{Zn}^{2+}$ and $\left.\mathrm{M}^{\prime}=\mathrm{Mn}^{2+}, \mathrm{Cd}^{2+}\right)\left(\mathrm{X}=\mathrm{NO}_{3}{ }^{-}, \mathrm{Cl}^{-}, \mathrm{ClO}_{4}{ }^{-}\right.$ and $\mathrm{X}_{2}=\mathrm{SO}_{4}{ }^{2-}$ ) (represented as MY throughout the text)) in oligo(ethylene oxide)-type noni onic surfactants $\left(\mathrm{C}_{n} \mathrm{H}_{2 n+1}\left(\mathrm{CH}_{2} \mathrm{CH}_{2} \mathrm{O}\right)_{m} \mathrm{OH}\right.$, represented as $\mathrm{C}_{n} \mathrm{EO}_{m}(\mathrm{n}=$ $12,16, m=10$ ) by means of heat produces a new LLC system. The $\mathrm{Cl}^{-}$and $\mathrm{SO}_{4}{ }^{2-}$ salts of the transition metals are hard to dissolve in a nonionic surfactant. Note that the $\mathrm{Cl}^{-}$and $\mathrm{SO}_{4}{ }^{2-}$ ions are lyotropic (or water-structuremakers) ions ${ }^{20,21}$ that reduce the hydrophilicity of the $\mathrm{EO}$ units of the $\mathrm{C}_{n} \mathrm{EO}_{\mathrm{m}}$-type surfactants in the water: salt:surfactant ternary LC systems. Also note that the LC phase of an oligo(ethylene oxide) nonionic surfactant and a transition metal salt of any lyotropic ions in the presence of water (at a low metal salt concentration in water:salt:surfactant systems) is stable. Since the solubility of the $\mathrm{Cl}^{-}$and $\mathrm{SO}_{4}{ }^{2-}$ salts of transition metal aqua complexes is extremely low in a salt:surfactant system, dissolving them in methanol or water and then mixing with $\mathrm{C}_{n} \mathrm{EO}_{\mathrm{m}}$ depicts a hexagonal LC mesophase. However, during solvent evaporation, the mesophase undergoes phase separation into metal salt crystals and surfactant molecules in a very short time.

All the transition metal nitrate hexa- and tetrahydrate $\left[\mathrm{M}\left(\mathrm{H}_{2} \mathrm{O}\right)_{6}\right]\left(\mathrm{NO}_{3}\right)_{2}$ salts used in this work can be dissolved in $\mathrm{C}_{12} \mathrm{EO}_{10}$ and $\mathrm{C}_{16} \mathrm{EO}_{10}$ to produce a $\mathrm{LC}$ mesophase with a few heating/cooling cycles. At a nitrate salt:surfactant mole ratio of up to 3.2 (ca. 40$60 \% \mathrm{w} / \mathrm{w}$ salt to surfactant) and between a 1.2 and a 3.2 mole ratio, the mixtures are ani sotropic and display focal conic fan textures under POM (Figure 1). If the nitrate salt concentration is not very high (below a mole ratio of 2.5:1.0 salt:surfactant), the LLC phases are stable for years.

The perchlorate salts of the same metal aqua complexes behave differently. In those, the surfactant molecules prefer to organize into a cubic mesophase. It is important to note that the solubility of the $\mathrm{ClO}_{4}{ }^{-}$ transition metal salts is intermediate between the nitrates and chlorides. Dissolving some of the metal perchlorates in $\mathrm{C}_{12} \mathrm{EO}_{10}$ takes a couple of days to form a homogeneous mixture with a LC mesophase. The

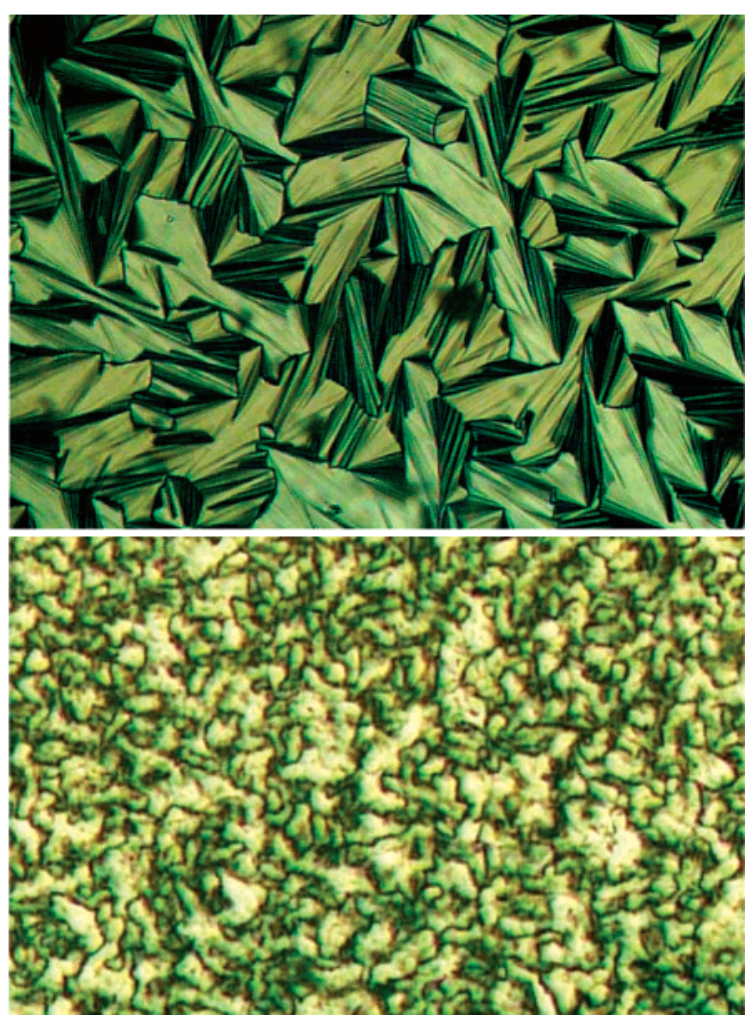

Figure 1. POM images of $2 \mathrm{D}$ hexagonal $\mathrm{LC}\left[\mathrm{Cd}\left(\mathrm{H}_{2} \mathrm{O}\right)_{4}\right]\left(\mathrm{NO}_{3}\right)_{2}$ : $\mathrm{C}_{12} \mathrm{EO}_{10}$ (top) and 3D hexagonal $\left[\mathrm{Mn}\left(\mathrm{H}_{2} \mathrm{O}\right)_{4}\right]\left(\mathrm{NO}_{3}\right)_{2}: \mathrm{C}_{12} \mathrm{EO}_{10}$ (bottom).

$\mathrm{ClO}_{4}^{-}$salts of $\mathrm{Co}(\mathrm{II}), \mathrm{Mn}(\mathrm{II}), \mathrm{Zn}(\mathrm{II})$, and $\mathrm{Cd}(\mathrm{II})$ have been tested in the context of this work. For example, the LC mesophase formed mixing $\mathrm{C}_{12} \mathrm{EO}_{10}$ or $\mathrm{C}_{16} \mathrm{EO}_{10}$ and $\left[\mathrm{M}\left(\mathrm{H}_{2} \mathrm{O}\right)_{n}\right]\left(\mathrm{ClO}_{4}\right)_{2}$ salts in various salt:surfatant ratios is isotropic; however, it is anisotropic if $\mathrm{C}_{18} \mathrm{EO}_{20}$ is used. The phase behavior of $\mathrm{C}_{18} \mathrm{EO}_{20}$ will be discussed elsewhere. Unlike that of nitrates, the perchlorate salt: surfactant LLC mesophase undergoes crystallization into perchlorate salt and surfactant in a few days.

The thermal properties of the salt:surfactant binary LLC mesophases were determined using a hot stage attached to a polarizing optical microscope. The phase transitions, from a LC mesophase to a liquid phase or from a cubic mesophase to a hexagonal mesophase and then to a liquid phase, were determined for a broad range of $M Y: \mathrm{C}_{12} \mathrm{EO}_{10}$ mixtures. ${ }^{25}$ The cubic phase for the nitrates appear above a 3.0 and 3.2 mole ratio for the $\mathrm{CdY}: \mathrm{C}_{12} \mathrm{EO}_{10}$ and $\mathrm{ZnY}: \mathrm{C}_{12} \mathrm{EO}_{10}$, respectively. This phase is optically isotropic and shows a phase transition to an anisotropic phase upon heating. The saturation point for dissolving the zinc nitrate salt is reached at a mole ratio of $\approx 5$ in the $\mathrm{C}_{12} \mathrm{EO}_{10}$ system, in which the LC phase is not stable for more than a day. The CdY: $\mathrm{C}_{12} \mathrm{EO}_{10}$ system does not show crystallization up to a mole ratio of 7.0, but it appears that, at this concentration, the mixture does not have a mesophase.

To expand, the LC phases were also constructed in water by adding the $\left[\mathrm{Ni}\left(\mathrm{H}_{2} \mathrm{O}\right)_{6}\right]\left(\mathrm{NO}_{3}\right)_{2}$ or $\left[\mathrm{Co}\left(\mathrm{H}_{2} \mathrm{O}\right)_{6}\right]-$ $\left(\mathrm{NO}_{3}\right)_{2}$ or $\left[\mathrm{Co}\left(\mathrm{H}_{2} \mathrm{O}\right)_{6}\right] \mathrm{Cl}_{2}$ salts in a $\mathrm{LC}$ mixture of $50 / 50$ wt $\% \mathrm{H}_{2} \mathrm{O}: \mathrm{C}_{n} \mathrm{EO}_{\mathrm{m}}$ or first by dissol ving the salt in water and then adding surfactant to form a LLC ternary system. The water:salt:surfactant ternary systems are stable up to a 0.8-1.0 salt:surfactant mole ratio in 50/ 50 wt \% water:surfactant and forms a hexagonal LC 
Table 1. Isotropization Temperature of the Hexagonal LC Mesophases of $\left[\mathrm{Ni}\left(\mathrm{H}_{2} \mathrm{O}\right)_{6}\right]\left(\mathrm{NO}_{3}\right)_{2},\left[\mathrm{Co}\left(\mathrm{H}_{2} \mathrm{O}\right)_{6}\right]\left(\mathrm{NO}_{3}\right)_{2}$, and $\left[\mathrm{Co}\left(\mathrm{H}_{2} \mathrm{O}\right)_{6}\right] \mathrm{Cl}_{2}$ in $50 \% \mathrm{w} / \mathrm{w} \mathrm{H}_{2} \mathrm{O}: \mathrm{C}_{12} \mathrm{EO}_{10}$

\begin{tabular}{|c|c|c|c|}
\hline \multirow{2}{*}{$\begin{array}{c}\mathrm{MY}: \mathrm{C}_{12} \mathrm{EO}_{10} \\
(\mathrm{~mol}) \text { in } 50 \% \mathrm{w} / \mathrm{w} \\
\mathrm{H}_{2} \mathrm{O}: \mathrm{C}_{12} \mathrm{EO}_{10}\end{array}$} & \multicolumn{3}{|c|}{$\begin{array}{l}\text { transition metal aqua complexes, } \\
\text { isotropization temperature }\left({ }^{\circ} \mathrm{C}\right)\end{array}$} \\
\hline & $\begin{array}{l}{\left[\mathrm{Ni}\left(\mathrm{H}_{2} \mathrm{O}\right)_{6}\right]-} \\
\quad\left(\mathrm{NO}_{3}\right)_{2}\end{array}$ & $\begin{array}{l}{\left[\mathrm{Co}\left(\mathrm{H}_{2} \mathrm{O}\right)_{6}\right]-} \\
\left(\mathrm{NO}_{3}\right)_{2}\end{array}$ & $\begin{array}{c}{\left[\mathrm{Co}\left(\mathrm{H}_{2} \mathrm{O}\right)_{6}\right]-} \\
\mathrm{Cl}_{2}\end{array}$ \\
\hline 0 & 60.5 & 60.5 & 60.5 \\
\hline 0.2 & 60.9 & 61.4 & 57.2 \\
\hline 0.4 & 62.4 & 62.5 & 53.8 \\
\hline 0.6 & 63.5 & 60.6 & 53.2 \\
\hline 0.8 & 63.8 & 63.3 & 51.0 \\
\hline 1.0 & 64.4 & 62.9 & 50.1 \\
\hline
\end{tabular}

mesophase. The hexagonal LC to liquid phase transitions were recorded in the same way as before (Table 1). The $\left[\mathrm{Ni}\left(\mathrm{H}_{2} \mathrm{O}\right)_{6}\right]\left(\mathrm{NO}_{3}\right)_{2}$ and $\left[\mathrm{Co}\left(\mathrm{H}_{2} \mathrm{O}\right)_{6}\right]\left(\mathrm{NO}_{3}\right)_{2}$ salts have very little effect on the phase transition temperatures with increasing salt concentration. The LC mesophase of a 50 wt $\% \mathrm{C}_{12} \mathrm{EO}_{10}: \mathrm{H}_{2} \mathrm{O}$ has an IT around $60{ }^{\circ} \mathrm{C}$ and it only increases by $4-5^{\circ} \mathrm{C}$ in a broad range of transition nitrate salts. However, in the case of chloride salt, the ITs decrease a few degrees with increasing metal aqua complex concentration compared to a $\mathrm{H}_{2} \mathrm{O}: \mathrm{C}_{12} \mathrm{EO}_{10}(50 \% \mathrm{w} / \mathrm{w})$ mesophase. Since the chlorite ion is known as a lyotropic anion, which has a "salting-out" effect, it is expected to dehydrate the EO chain. The sample viscosity also decreases with an increasing salt concentration; at around a 1.0 mole ratio the mixtures are in the liquid phase. However, the LC phase, which is directly prepared from metal aqua complexes and dry nonionic surfactant, $\mathrm{MY}: \mathrm{C}_{12} \mathrm{EO}_{10}$, becomes thicker and the ITs increase with an increasing salt concentration. ${ }^{25}$ The change on the ITs in some samples can go up to almost $80^{\circ} \mathrm{C}$, going from a 1.2 to 3.2 $\mathrm{MY}: \mathrm{C}_{12} \mathrm{EO}_{10}$ mole ratio.

The FT-IR spectroscopy has been extensively used to obtain information regarding the structure of poly(ethylene oxide) surfactant molecules in the presence of metal complexes. ${ }^{27-33}$ The oligo(ethylene oxide), $\mathrm{C}_{\mathrm{n}^{-}}$ $\mathrm{EO}_{\mathrm{m}}$ surfactants, such as $\mathrm{C}_{12} \mathrm{EO}_{10}$, undergo changes in thier conformation upon mixing with water and/or aqua complexes of transition metal ions due to hydrogenbonding interactions between polar $\mathrm{EO}$ headgroup and water molecules. There are two regions $(v-\mathrm{OH}$ and $v$-CO stretching) of the mid-IR spectrum that show hydrogenbonding interactions between water (both free and coordinated) and surfactant molecules. The $v-(\mathrm{OH})$ stretching modes for molten surfactant, surfactant/ water (50 wt \%), and $\mathrm{CdY}: \mathrm{C}_{12} \mathrm{EO}_{10}$ mixtures are observed at 3480,3425 , and $3370 \mathrm{~cm}^{-1}$, respectively (Figure 2A). The $v$-(CO) stretching band at $1115 \mathrm{~cm}^{-1}$ for the molten surfactant shifts to 1100 and $1087 \mathrm{~cm}^{-1}$ in the presence of water and metal aqua complexes, respectively ( $F$ igure $2 \mathrm{~B}$ ). These indicate that hydrogen bonding in a $\mathrm{MY}: \mathrm{C}_{12} \mathrm{EO}_{10} \mathrm{LC}$ binary mesophase is

(27) Nito, V. D.; Longo, D.; Münchow, V. J . Phys. Chem. B 1999, 103, 2636.

(28) Matsuura, H.; Fukuhara, K. J . Polym. Sci. Part B: Polym. Phys. 1986, 24, 1383.

(29) Kimura, N .; Umemura, J.; Hayashi, S. J . Colloid I nterface Sci. 1996, 182, 356

(30) Mädler, B.; Binder, H.; Klose, G. J . Colloid InterfaceSci. 1998 202, 124.

(31) Frech, R.; Huang, W. Macromolecules 1995, 28, 1246

(32) Rhodes, C. P.; Frech, R. Macromolecules 2001, 34, 1365.

(33) Matsuura, H.; Fukuhara, K.; Takashima, K.; Sakakibara, M. J. Phys. Chem. 1991, 95, 10800.
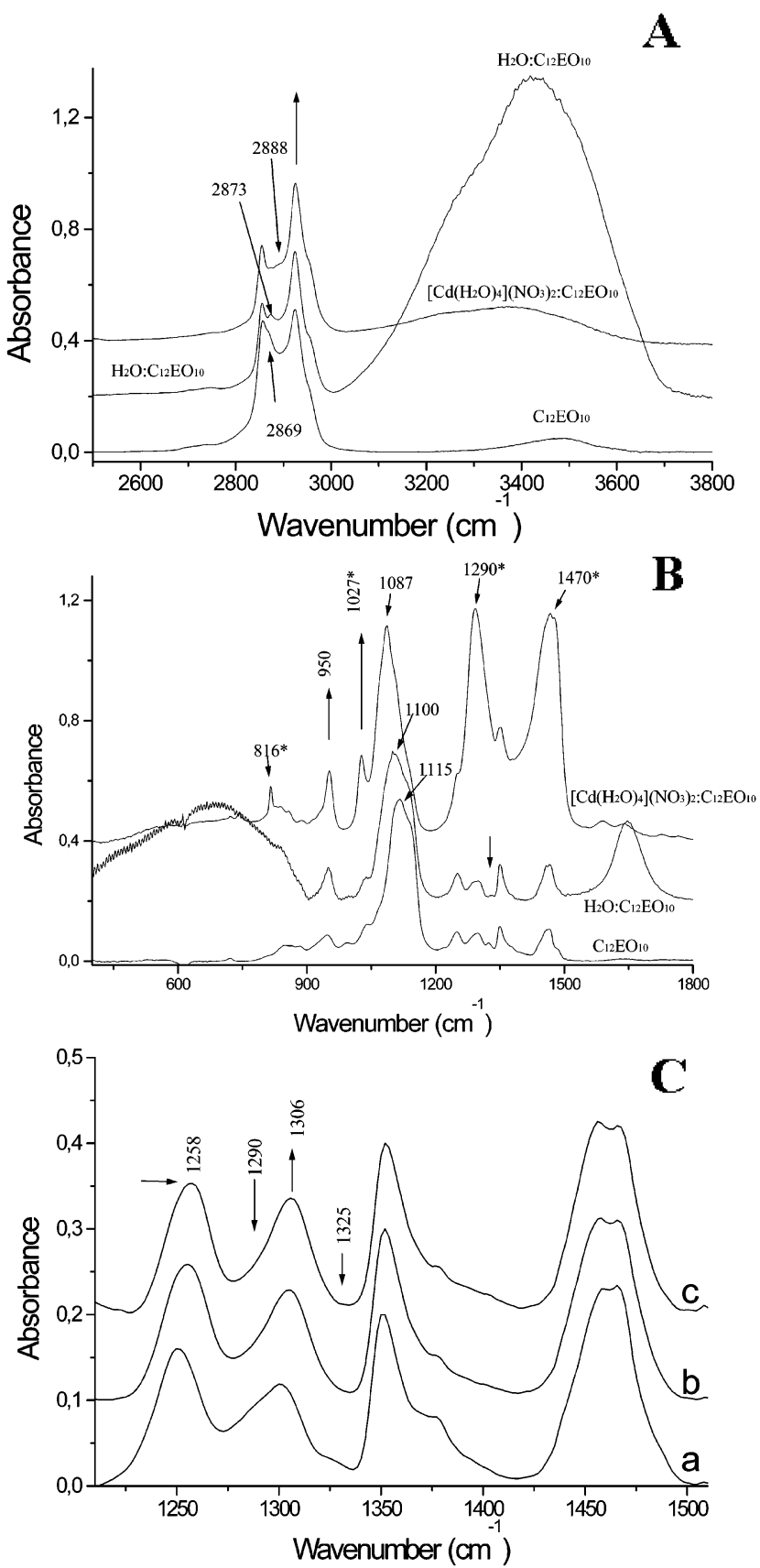

Figure 2. $(A, B) F T-I R$ spectra of molten surfactant, $\mathrm{LC}_{2} \mathrm{O}$ : $\mathrm{C}_{12} \mathrm{EO}_{10}(50 \% \mathrm{w} / \mathrm{w})$ and $\mathrm{LC}\left[\mathrm{Cd}\left(\mathrm{H}_{2} \mathrm{O}\right)_{4}\right]\left(\mathrm{NO}_{3}\right)_{2}: \mathrm{C}_{12} \mathrm{EO}_{10}$ (* on the wavenumbers are due to free and coordinated $\mathrm{NO}_{3}{ }^{-}$ion); (C) FTIR spectra of $\left[\mathrm{Co}\left(\mathrm{H}_{2} \mathrm{O}\right)_{6}\right]\left(\mathrm{ClO}_{4}\right)_{2} / \mathrm{C}_{12} \mathrm{EO}_{10}$ systems with $\mathrm{Co}^{2+}$ $\mathrm{C}_{12} \mathrm{EO}_{10}$ mole ratios of (a) 0.5 , (b) 1.5 , and (c) 2.5 .

stronger than that in a $\mathrm{H}_{2} \mathrm{O}: \mathrm{C}_{12} \mathrm{EO}_{10}$ mesophase. The strength of the hydrogen bonding between the metal complex ions and the surfactant molecules are also reflected on the IT in that it increases with increasing metal salt concentrations in the salt:surfactant LC systems. ${ }^{25}$

In an aqueous solution of nonionic surfactant or molten surfactant, the vibrational peaks are broader compared to crystalline poly(oxyethylene) (POE) polymers because the POE chain in a crystalline state has a well-ordered helical structure 28,34 in which the $\left(-\mathrm{CH}_{2}-\right.$

(34) Murcko, M. A.; DiPaola, R. A. J . Am. Chem. Soc. 1992, 114, 10010. 


\section{Scheme 1}

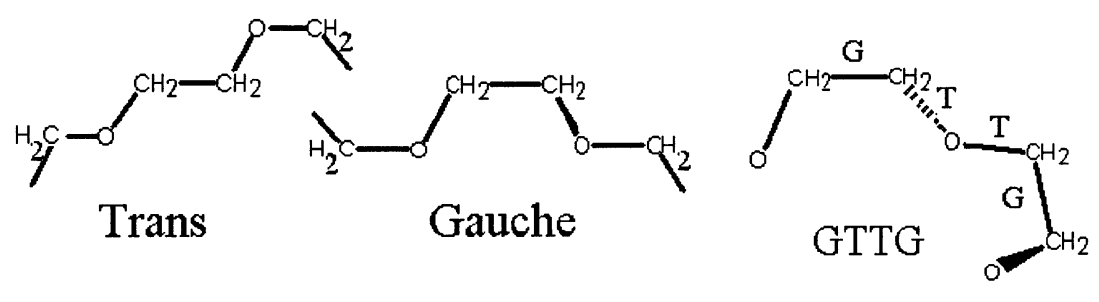

$\mathrm{CH}_{2}-\mathrm{O}-\mathrm{CH}_{2}-\mathrm{CH}_{2}-$ ) units are in GTTG conformers (G and $\mathrm{T}$ stand for gauche and trans conformers, respectively, see Scheme 1).

In a nonionic surfactant, $\mathrm{C}_{\mathrm{n}} \mathrm{EO}_{\mathrm{m}}$, the ethoxy methylenes absorb at distinctly higher frequencies than the alkyl methylenes. ${ }^{35}$ The $v$ - $\left(\mathrm{CH}_{2}\right)$ stretching band of ethoxy units of $\mathrm{C}_{12} \mathrm{EO}_{10}$ has been observed as a shoulder at $2869 \mathrm{~cm}^{-1}$. This band shifts to 2873 and $2888 \mathrm{~cm}^{-1}$, by adding water and metal aqua complex, respectively, due to a change in conformation. For instance, the $\mathrm{CH}_{2}$ wagging vibration appears at around $1380-1350 \mathrm{~cm}^{-1}$ if the $\mathrm{C}-\mathrm{C}$ bond has a $\mathrm{G}$ conformer and at around $1355-1320 \mathrm{~cm}^{-1}$ if it has a T conformer (Figure 2). Therefore, the band at $1325 \mathrm{~cm}^{-1}$ has been assigned to a $\mathrm{T}$ conformer of a $\mathrm{C}-\mathrm{C}$ bond. ${ }^{28}$ It loses its intensity and shifts to a higher energy in water:surfactant LC systems and disappears in $M Y: C_{n} E O_{m}$ mesophases (Figure 2C). This is a clear indication of a $T$ to a $G$ conformation change in the $\mathrm{C}-\mathrm{C}$ bonds. Moreover, similar behaviors are also observed in $\mathrm{CH}_{2}$ symmetric and antisymmetric twisting vibrational modes of $\mathrm{O}-$ $\mathrm{CH}_{2}-\mathrm{CH}_{2}-\mathrm{O}$ segments. These two modes also show that not all EO chains have a GTTG conformer in their $-\mathrm{CH}_{2}-\mathrm{CH}_{2}-\mathrm{O}-\mathrm{CH}_{2}-\mathrm{CH}_{2}-$ units in the MY: $\mathrm{C}_{12} \mathrm{EO}_{10}$ LC mesophase; however, some of the $\mathrm{C}-\mathrm{O}$ bonds have $\mathrm{G}$ conformation as well.

Weak and broad $v$-CO stretching and $\mathrm{CH}_{2}$ rocking signals, ${ }^{28,35,36}$ in the $800-900-\mathrm{cm}^{-1}$ region, become narrower and sharper in the $M Y: C_{12} E_{10}$ mesophase. The peak above $825 \mathrm{~cm}^{-1}$ is assigned to a $\mathrm{G}$ conformer and the one at around $810 \mathrm{~cm}^{-1}$ to a T conformer of $\mathrm{a} \mathrm{OCH}_{2}-$ $\mathrm{CH}_{2} \mathrm{O}$ unit. ${ }^{28,31,32}$ However, there is also a sharp and relatively intense peak of the nitrate ion ${ }^{26}$ at around $810 \mathrm{~cm}^{-1}$. The spectrum of a $\left[\mathrm{Co}\left(\mathrm{H}_{2} \mathrm{O}\right)_{6}\right] \mathrm{Cl}_{2}: \mathrm{C}_{12} \mathrm{EO}_{10}$ binary mesophase is useful for the resolution of this region. It displays a peak at $846 \mathrm{~cm}^{-1}$, indicating the presence of a $\mathrm{G}$ conformation on $\mathrm{OCH}_{2}-\mathrm{CH}_{2} \mathrm{O}$ units of nonionic surfactants in LC mesophase ( $\mathrm{F}$ igure $2 \mathrm{~B}$ ). Also note that there is no peak observed at around $810 \mathrm{~cm}^{-1}$ for the $\left[\mathrm{Co}\left(\mathrm{H}_{2} \mathrm{O}\right)_{6}\right]\left(\mathrm{ClO}_{4}\right)_{2}: \mathrm{C}_{12} \mathrm{EO}_{10}$ binary mesophase. All the evidence shows that there is an appreciable amount of $\mathrm{T}$ to $\mathrm{G}$ conformation changes going from a molten surfactant into a LC salt:surfactant mesophase.

Recently, we presented the nitrate salt: $\mathrm{C}_{12} \mathrm{EO}_{10}$ system using FT-IR spectroscopy to elucidate the nature of nitrate ions in the LC media. ${ }^{26}$ Splitting of doubly degenerate asymmetric stretching and bending modes, observation of IR inactive symmetric stretching, and combination modes from nitrate ion are all strong evidence supporting the coordination of nitrate ion to a metal center. ${ }^{26} \mathrm{The} \mathrm{ClO}_{4}{ }^{-}$ion vibrational modes, however, do not respond to changes in the perchlorate salt

(35) Frech, R.; Huang, W. Macromolecules 1995, 28, 1246.

(36) Rhodes, C. P.; F rech, R. Macromol ecules 2001, 34, 1365. concentration and/or water content of the media. The $\mathrm{CH}_{2}$ twisting, wagging, and rocking modes behave similarly to those of nitrates. Figure $2 \mathrm{C}$ displays free $\mathrm{ClO}_{4}{ }^{-}$ion-related peaks, which intensify with an increasing salt concentration at $625 \mathrm{~cm}^{-1}, T_{2}$ IR active mode of free perchlorate ion, and at $929 \mathrm{~cm}^{-1}, A_{1}$ IR inactive but gain intensity due to the formation of a $\mathrm{M}^{+} \mathrm{ClO}_{4}^{-}$ion pair. Therefore, perchlorate ions exist as a free ion and ion pair ${ }^{37}$ in the LC mesophase.

The XRD pattern of the nitrates of $\mathrm{C}_{12} \mathrm{EO}_{10}$ binary systems display the first three diffraction lines at around 48-, 28-, and 24- $\AA$ d spacings (Figure $3 a$ ). Some samples display up to five diffraction lines associated with $\mathrm{P} 6 \mathrm{~mm}$ 2D-hexagonal symmetry with a unit cell parameter $\mathrm{a}=55.4 \AA .{ }^{38}$ The manganese nitrate salt: $\mathrm{C}_{12} \mathrm{EO}_{10}$ and cobalt nitrate: $\mathrm{C}_{16} \mathrm{EO}_{10}$ mesophases display first three lines ${ }^{26}$ of a 3D hexagonal mesophase (Figure 3b). In a 2D-hexagonal mesophase, the assigned 38,39 reciprocal spacing, $1 / \mathrm{d}_{\mathrm{hk}}$, ratios of XRD lines are $1,3^{1 / 2}$, $2,7^{1 / 2}$, and 3 (Figure 3a). The diffraction lines observed in our samples generally coincide well with these assignments. However, most samples diffract two lines ((100) and (200) lines) with very similar POM images to those samples which diffract more than two lines. Similar diffraction patterns were observed from the mesostructured oriented silica film materials in which the (110) line is missing due to the orientation of the channels in one direction. ${ }^{40-42} \mathrm{~F}$ or example, rubbing the substrate in a parallel direction yields silica channels highly oriented in one direction. The mesoporous silica materials, prepared on a $\mathrm{Si}(100)$ surface, al so give two diffraction lines, (100) and (200), without (110) and (210). However, crushing these samples into fine powders or somehow removing the orientation results in a strong (100) with relatively weak (110), (200), and (210) lines. ${ }^{41,42}$ Some of our samples also diffract two lines, (100) and (200), but upon perturbation the orientation (110) line of the 2D hexagonal phase appears (Figure 3a).

The 3D hexagonal mesophase was observed in [M n$\left.\left(\mathrm{H}_{2} \mathrm{O}\right)_{4}\right]\left(\mathrm{NO}_{3}\right)_{2}: \mathrm{C}_{12} \mathrm{EO}_{10}$ and $\left[\mathrm{Co}\left(\mathrm{H}_{2} \mathrm{O}\right)_{6}\right]\left(\mathrm{NO}_{3}\right)_{2}: \mathrm{C}_{16} \mathrm{EO}_{10}$ mesophases between 1.2 and 3.0 salt-to-surfactant mole ratios. Figure 3b shows two diffraction patterns of [Co$\left.\left(\mathrm{H}_{2} \mathrm{O}\right)_{6}\right]\left(\mathrm{NO}_{3}\right)_{2}: \mathrm{C}_{16} \mathrm{EO}_{10}$ with a salt:surfactant mole ratio of 2.0, recorded by rotating the sample with respect to the detector axis. All the lines are sensitive to the sample position. For example, the intensity of (100),

(37) Ratcliffe, C. I.; Irish, D. E. Can. J . Chem. 1984, 62, 1134. 147 1147.

(38) Huo, Q.; Margolese, D. I.; Stucky, G. D. Chem. Mater. 1996, 8 ,

(39) Reppy, M. A.; Gray, D. H.; Pindzola, B. A.; Simithers, J . L.; Gin, D. L. J . Am. Chem. Soc. 2001, 123, 363.

(40) Yang, H.; Coombs, N.; Sokolov, I .; Ozin, G. A. J . Mater. Chem. 1997, 7, 1285.

(41) Miyata, H.; Kuroda, K. Chem. Mater. 1999, 11, 1609.

(42) Miyata, H.; Kuroda, K. Chem. Mater. 2000, 12, 49. 

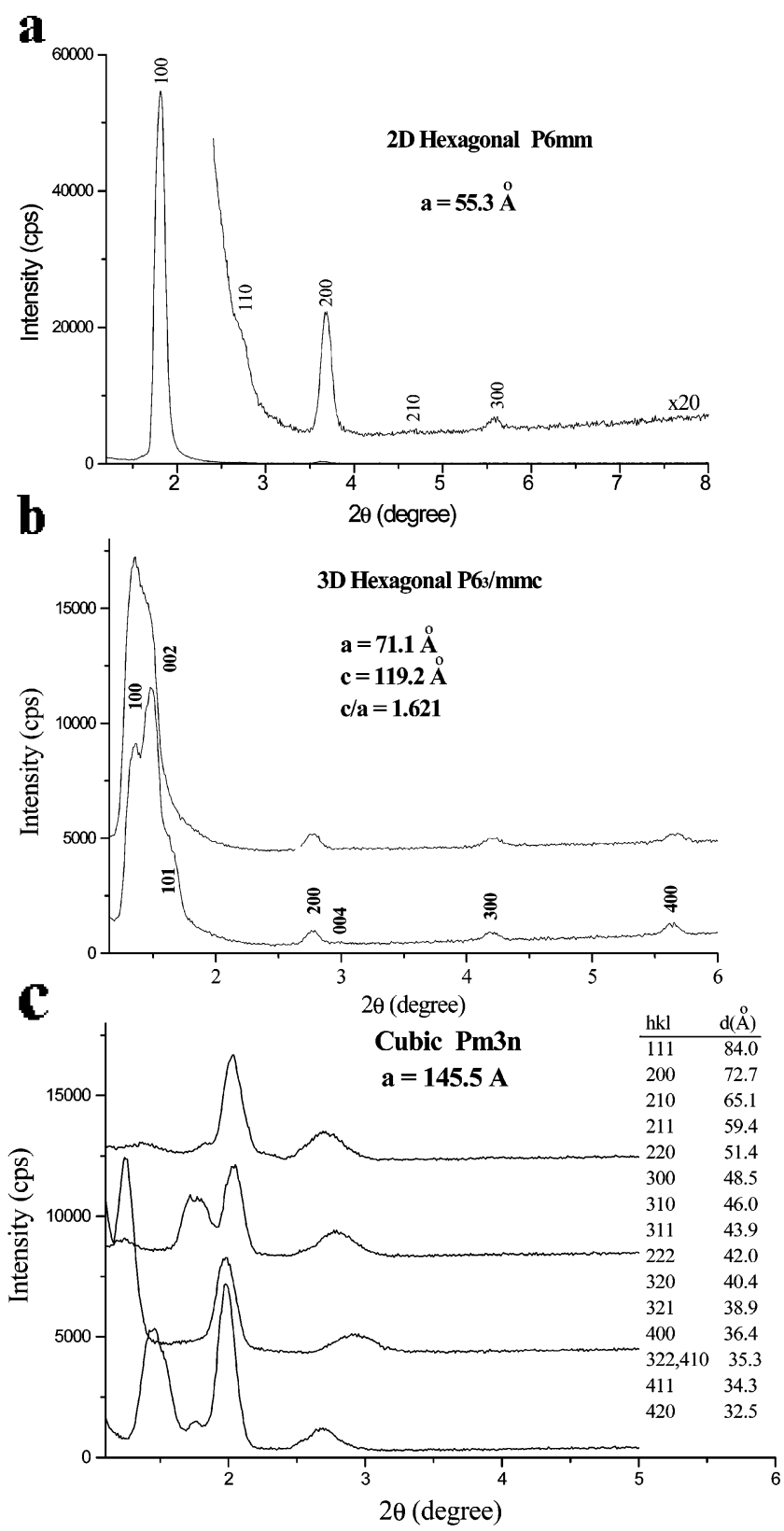

Figure 3. XRD patterns of (a) $2 \mathrm{D}$ hexagonal $\left[\mathrm{Zn}\left(\mathrm{H}_{2} \mathrm{O}\right)_{6}\right]\left(\mathrm{NO}_{3}\right)_{2}$ : $\mathrm{C}_{12} \mathrm{EO}_{10}$, (b) 3D hexagonal $\left[\mathrm{Co}\left(\mathrm{H}_{2} \mathrm{O}\right)_{6}\right]\left(\mathrm{NO}_{3}\right)_{2}: \mathrm{C}_{16} \mathrm{EO}_{10}$, and (c) cubic $\left[\mathrm{Co}\left(\mathrm{H}_{2} \mathrm{O}\right)_{6}\right]\left(\mathrm{ClO}_{4}\right)_{2}: \mathrm{C}_{12} \mathrm{EO}_{10}$.

(200), (300), and (400) lines give the same response to rotation of the sample. Similarly, (002) and (004) lines gain intensity in certain positions, while the (100), (200), (300), and (400) lines are suppressed, indicating an oriented 3D hexagonal mesophase. The unit cell parameters are $\mathrm{a}=73.5 \AA$ and $\mathrm{c}=119.2 \AA$ with $\mathrm{c} / \mathrm{a}=1.621$ with a space group of $\mathrm{P}_{3} / \mathrm{mmc}$. Similarly, the $[\mathrm{Mn}$ $\left.\left(\mathrm{H}_{2} \mathrm{O}\right)_{4}\right]\left(\mathrm{NO}_{3}\right)_{2}: \mathrm{C}_{12} \mathrm{EO}_{10}$ forms a 3D hexagonal mesophase that has three diffraction lines corresponding to the (100), (002), and (101) planes with unit cell parameters of $a=59.6 \AA$ and $c=48.6 \AA$ with $c / a=1.631$. This value is very close to 1.633 for the geometrical ratio in closed packed 3D hexagonal structures.

Like in the higher metal nitrate concentrations (nitrate salt-to-surfactant mole ratio of above 3.2), the perchlorate salt:surfactant mixtures are also isotropic between the crossed polarizers. However, they diffract at low angles, characteristic of a cubic mesophase. For example, $\left[\mathrm{Co}\left(\mathrm{H}_{2} \mathrm{O}\right)_{6}\right]\left(\mathrm{ClO}_{4}\right)_{2}: \mathrm{C}_{12} \mathrm{EO}_{10}$ samples have lowangle diffractions up to 10 lines which can be indexed to the Pm3n cubic space group with a unit cell parameter $\mathrm{a}=145 \AA$. H owever, the perchlorate samples have a dynamic diffraction pattern that changes with time. Figure $3 c$ shows the diffraction pattern recorded simultaneously from a sample of $2.00\left[\mathrm{Co}\left(\mathrm{H}_{2} \mathrm{O}\right)_{6}\right]\left(\mathrm{ClO}_{4}\right)_{2} / \mathrm{C}_{12^{-}}$ $\mathrm{EO}_{10}$ mole ratio. All the lines are connected with the $\mathrm{Pm} 3 \mathrm{n}$ space group but the intensity of the lines change with time. Further studies are required to elucidate the origin of the time-dependent changes. However, these samples are not stable for a long period of time. It undergoes phase separation into a crystalline salt and a dilute salt:surfactant disordered phase.

While the nitrate ion is coordinating to the metal center and reducing the ionic strength and/or ion density of the medium, the perchlorate ion remains free in the LC media. Since $\mathrm{ClO}_{4}{ }^{-}$ion has a smaller charge density, high polarizability, and a large radius compared to $\mathrm{NO}_{3}{ }^{-}$ ion, it prefers to remain free in the LC media. Another important behavior of perchlorate ion is that it makes the surfactant molecules more soluble and less rigid. Therefore, the surfactant molecules sense the charge density of the media and rearrange themselves into the energetically most favored conformation. We are currently working toward elucidating the structural properties of binary LC mesophases using various anion salts in the Hofmeister series. ${ }^{43}$

Mesostructured CdS (meso-CdS). The reaction of $\mathrm{H}_{2} \mathrm{~S}$ with the $\mathrm{LC}\left[\mathrm{Cd}\left(\mathrm{H}_{2} \mathrm{O}\right)_{4}\right]\left(\mathrm{NO}_{3}\right)_{2}: \mathrm{C}_{12} \mathrm{EO}_{10}$ mesophases produced mesotructured CdS. The product was washed in ethanol-diethyl ether solution several times to obtain a fine powder of the mesostructured CdS. A typical SEM image of a representative powder sample is shown in Figure 4A. Note that the size of the particles varies between $50 \mathrm{~nm}$ and $1.0 \mu \mathrm{m}$ with a spherical morphology (Figure 4A). The PXRD pattern shows a broad diffraction in that it tails from 1.0 to $2.5^{\circ}$. It is difficult to evaluate its structure and the unit cell parameters. The TEM images of the washed meso-CdS particles show a disordered structure in mesoscale (Figure 4B). Therefore, the observed image is consistent with the PXRD pattern. The walls of mesostructured CdS, however, broadly diffract at high angles, corresponding to a zinc blend structure, indicating nanocrystalline walls. The particle size, which is obtained using the diffraction pattern and the Scherrer's equation, is on average between 2.4 and $3.0 \mathrm{~nm}$, which is consistent with the TEM images.

The micro-Raman spectra of the powder samples display an intense fundamental band at $301 \mathrm{~cm}^{-1}$ and first and second overtones with a decreasing intensity at 602 and $905 \mathrm{~cm}^{-1}$, respectively. Alivisatos et al. ${ }^{44}$ has demonstrated a nice correlation between the ratio of the fundamental band intensity to that of the first overtone of CdS nanoparticles and particle size. The particle size has also been evaluated using Brus's effective mass model ${ }^{45}$ and the optical band gap obtained from the direct-gap fitting of the absorption edge of mesostructured CdS. The particle size that is evaluated from the

(43) Hofmeister, F. Arch. Exp. Pathol. Pharmakol. 1888, 24, 247

(44) Shiang, J. J .; Risbud, S. H.; Alivisatos, A. P. J . Chem. Phys. $1993,98,8432$

(45) Brus, L. J . Phys. Chem. 1986, 90, 2555. 

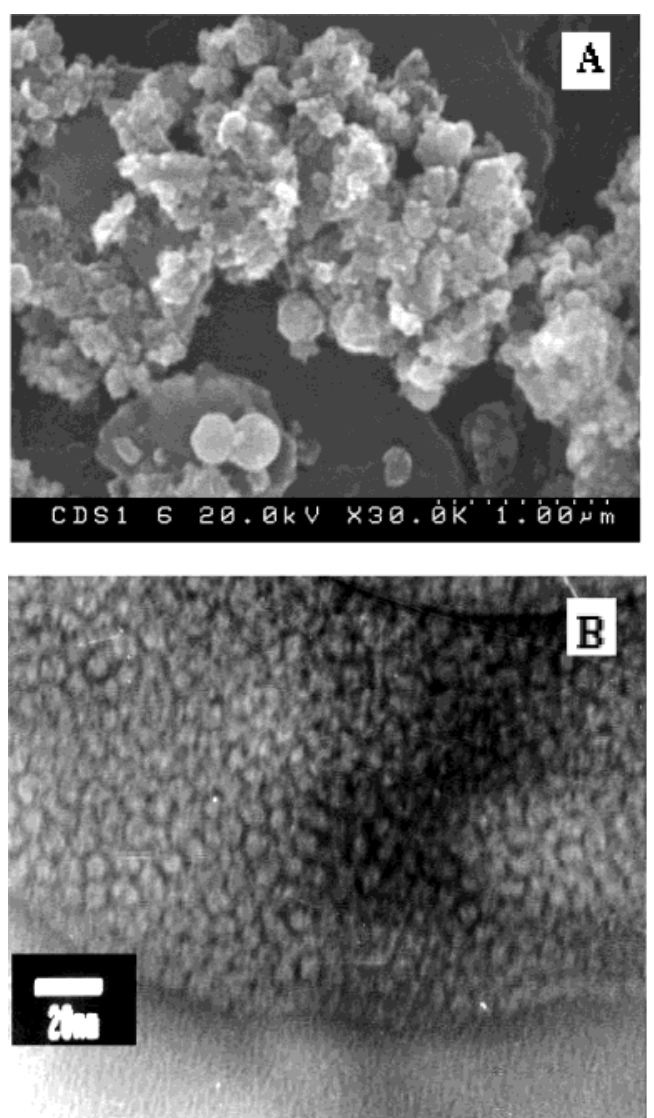

Figure 4. (A) SEM and (B) TEM images of meso-CdS powder after washing with ethanol-ether mixture synthesized using $\mathrm{LC}\left[\mathrm{Cd}\left(\mathrm{H}_{2} \mathrm{O}\right)_{4}\right]\left(\mathrm{NO}_{3}\right)_{2}: \mathrm{C}_{12} \mathrm{EO}_{10}$ mesophase and $\mathrm{H}_{2} \mathrm{~S}$, showing spherical morphology and the mesostructured nature of the washed materials, respectively.

Raman intensity and the band gap measured from UV vis absorption measurements ${ }^{46}$ are both consistent with the PXRD measurements.

The UV - vis absorption edge blue-shifts in all samples compared to the bulk CdS absorption edge (the bulk optical band gap is $2.42 \mathrm{eV}$ at RT); see Figure 5 . The blue shift on the absorption edge is a clear indication that the meso-CdS is made up of nanoparticles. The blue shift of the absorption edge may originate from the confinement of electrons and holes (quantum size effect) in pore walls. The band-gap energies of the samples, prepared using various $\mathrm{MY}: \mathrm{C}_{12} \mathrm{EO}_{10}$ mole ratios, are tabulated in Table 2. The absorption edge seems to be sensitive to the concentration of metal ion in $\left[\mathrm{Cd}\left(\mathrm{H}_{2} \mathrm{O}\right)_{4}\right]-$ $\left(\mathrm{NO}_{3}\right)_{2}: \mathrm{C}_{12} \mathrm{EO}_{10} \mathrm{LC}$ mesophase (Table 2). The band-gap energy approaches the bulk value at higher salt concentrations. Further investigations are ongoing to elucidate questions on the formation of mesostructured $\mathrm{CdS}$, the effect of the salt concentration, reaction temperature, pressure of the $\mathrm{H}_{2} \mathrm{~S}$ gas, and the counteranion in the binary systems.

\section{Conclusions}

In summary, the transition metal aqua complex salts of the hydrotropic anions, such as $\mathrm{NO}_{3}{ }^{-}$and $\mathrm{ClO}_{4}{ }^{-}$, have a lyotropic liquid-crystalline mesophase in $\mathrm{C}_{n} \mathrm{EO}_{\mathrm{m}}$-type

(46) Nedeljkovic, J. M.; Patel, R. C.; Kaufman, P.; J oyce-Pruden, C.; O'Leary, N. J . Chem. Educ. 1993, 70, 342.

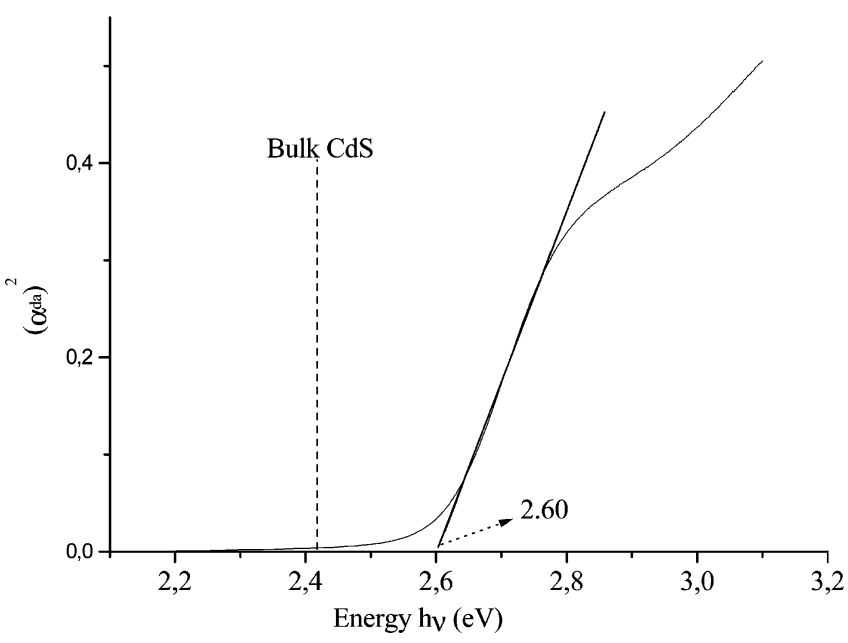

Figure 5. UV-vis absorption spectrum of meso-CdS synthesized using $1.8\left[\mathrm{Cd}\left(\mathrm{H}_{2} \mathrm{O}\right)_{4}\right]\left(\mathrm{NO}_{3}\right)_{2}: \mathrm{C}_{12} \mathrm{EO}_{10}$ mole ratio; the spectrum is plotted square of the absorbance versus energy to see the direct-gap fit.

Table 2. Optical Band Gaps Measured from UV-Vis Absorption Spectra; Particle Size Obtained from Brus's Model $^{45,46}$ and from Scherrer's Equation (Using PXRD data) of the Meso-CdS Materialsa

\begin{tabular}{ccc}
\hline $\begin{array}{c}\text { optical band gap } \\
(\mathrm{eV})\end{array}$ & $\begin{array}{c}\text { particle size } \\
(\mathrm{nm})\end{array}$ & $\begin{array}{c}\text { particle size } \\
\text { from PXRD } \\
(\mathrm{nm})\end{array}$ \\
\hline $2.52(1.4)$ & $3.17(1.4)$ & $2.84(1.5)$ \\
$2.60(1.8)$ & $2.63(1.8)$ & $2.90(1.6)$ \\
$2.58(2.2)$ & $2.74(2.2)$ & $2.64(2.0)$ \\
$2.47(2.6)$ & $3.80(2.6)$ & $2.40(2.5)$ \\
$2.48(3.0)$ & $3.64(3.0)$ & $2.51(3.0)$ \\
$2.45(3.6)$ & $4.21(3.6)$ & $2.77(4.0)$
\end{tabular}

a Numbers in parentheses are the $\left[\mathrm{Cd}\left(\mathrm{H}_{2} \mathrm{O}\right)_{4}\right]\left(\mathrm{NO}_{3}\right)_{2} / \mathrm{C}_{12} \mathrm{EO}_{10}$ mole ratios. ${ }^{b}$ Bulk band gap is $2.42 \mathrm{eV}$.

nonionic surfactants. Metal nitrates form hexagonal mesophases, while perchlorate salts of the same metal ion form cubic mesophases. However, at higher nitrate concentrations, some transition metal nitrate salts also form a cubic mesophase. The nitrate salts are more soluble than perchlorate salts. The likely origin for this is the coordination ability of the nitrate ion to transition metal center. This lowers the charge of the complex ion and the ion density of the LC media, such that it increases the solubility of the nitrate salt in oligo(ethylene oxide)-type nonionic surfactants.

The reaction of the cadmium nitrate mesophase with $\mathrm{H}_{2} \mathrm{~S}$ gas produces mesostructured $\mathrm{CdS}$. The walls of the pores are made up of $2.0-4.0 \mathrm{~nm}$ CdS nanoparticles. The reaction between the LLC phase and $\mathrm{H}_{2} \mathrm{~S}$ gas and phase properties of the salt:surfactant systems will be further investigated to make better qual ity mesoporous metal sulfides.

Acknowledgment. For the financial support, Ö.D. gratefully acknowledges the Turkish Academy of Science in the framework of the Young Scientist Award (ÖD/TÜBA-GEBI P/2002-1-6), the Scientific and Technical Research Council of Turkey (TÜBITAK) in the framework of Project TBAG-2263 (102T188), and the Faculty Development grant of Bilkent University. 